\section{Evaluation of alveolar pneumatization in maxillary sinus and related factors by panoramic and CBCT imaging methods}

\section{Maksiller sinüste alveolar pnömatizasyon ve ilişkili faktörlerin panoramik ve kıbt görüntüleme yöntemleri ile değerlendirilmesi}

\author{
Dr. Fatmanur Ketenci \\ Yeditepe University, Faculty of Dentistry, \\ Department of Dentomaxillofacial Radiology, İstanbul \\ Orcid ID: 0000-0002-9618-1082
}

\section{Assoc. Prof. Defne Yalçın Yeler \\ Cumhuriyet University, Faculty of Dentistry, Department of Dentomaxillofacial Radiology, Sivas Orcid ID: 0000-0003-4801-0120}

Dt. Melike Koraltan

Sivas Dental Hospital, Sivas

Orcid ID: 0000-0002-8208-6666

Assist. Prof. Yener Ünal

Cumhuriyet University, Faculty of Science,

Department od Statistics, Sivas

Orcid ID: 0000-0002-4796-8276

Received: 13 February 2019

Accepted: 18 April 2019

doi: 10.5505/yeditepe.2019.73645

\section{Corresponding author:}

Fatmanur Ketenci

Yeditepe University, Faculty of Dentistry,

Bağdat Street No:238 34728 İstanbul

Phone: 02163636044

E-mail: fatmanur.ketenci90.fk@gmail.com

\section{SUMMARY}

Aim: Sinus pneumatization; is a physiological process that increases the volume of sinus. In dentistry, evaluation correctly of presence the alveolar pneumatization of maxillary sinus and relations between tooth root and the sinus floor is important because of prevent possible complications in dental treatments to be applied to posterior region. Therefore, this study aimed to identify the sensitivity, specificity and diagnostic accuracy of usually preferred panoramic radiography in dental clinics; in detecting alveolar pneumatization and the relations between dental roots and sinus floor compared to CBCT. Additionally, the aim of this study is to evaluate the prevalence of pneumatization in the Turkish sub-population and possible associations with sinus pathologies with CBCT imaging.

Materials and Method: 600 maxillary sinus images were examined with 'panoramic radiography and $\mathrm{CBCT}^{\text {'. In }}$ the maxillary sinuses; alveolar pneumatization, mucosal thickening and the presence of other pathologies and the relations between posterior tooth roots and sinus floor were recorded.

Conclusions: Alveolar pneumatization in $81.3 \%$ of patients, mucosal thickening in $63 \%$ and other pathologies in $31.7 \%$ of patients was found. There was a statistically significant difference between age groups in terms of pneumatization and relation between tooth root and sinus floor $(p<0.05)$. Presence or absence of posterior teeth was effective on pneumatization $(p<0.05)$.

Panoramic radiographs show tooth roots more closely related to the sinuses, especially when tooth root is adjacent to sinus. So dentist sometimes anticipates an unnecessary perforation risk, but this condition doesn't pose a risk for the patient. Therefore panoramic radiography can be used to evaluate the relation between tooh root and sinus floor, but CBCT should be preferred for definite diagnosis.

Keywords: Maxillary sinus, pneumatization, cone beam computed tomography, panoramic radiography

\section{ÖZET}

Amaç: Sinüs pnömatizasyonu; sinüs hacmini artıran fizyolojik bir süreçtir. Diş hekimliğinde, maksiller posterior bölgeye uygulanacak dental tedavilerde, maksiller sinüste alveolar pnömatizasyon varlığının ve diş köküsinüs ilişkisinin doğru bir şekilde değerlendirilmesi olası komplikasyonların önüne geçeceğinden dolayı önemlidir. Bu yüzden bu çalışma, klinikte sık tercih edilen panoramik görüntülemenin, konik ışınlı bilgisayarlı tomografiye (KIBT) kıyasla alveoler pnömatizasyon ve diş kökü- sinüs ilişkisini belirlemedeki sensitivite, spesifite ve tanısal doğruluk değerini tespit etmeyi amaçlamıştır. Ayrıca, bu çalışmanın amacı KIBT görüntüleme ile, Türk 
sub-populasyonundaki pnömatizasyon prevalansı ve alveoler pnömatizasyonların sinüs patolojileriyle ilgili olası ilişkilerini değerlendirmektir.

Gereç ve Yöntem: 600 maksiller sinüs görüntüsü panoramik radyografi ve KIBT ile incelendi. Maksiller sinüslerde alveolar pnömatizasyon, mukozal kalınlaşma ve diğer patolojilerin varlığı ile posterior diş kökleri ile sinüs tabanı arasındaki ilişki kaydedildi.

Bulgular: Hastaların \%81,3'ünde alveolar pnömatizasyon, \%63'ünde mukozal kalınlaşma ve \%31,7'sinde diğer patolojiler tespit edildi. Yaş grupları arasında pnömatizasyon ve diş kökü-sinüs ilişkisi açısından istatistiksel olarak anlamlı farklılık $(p<0,05)$ olduğu görüldü. Hastaların dişli ve dişsiz olma durumunun pnömatizasyon üzerinde etkili olduğu $(p<0,05)$ saptandı.

Sonuçlar: Panoramik radyografiler özellikle dişin sinüse komşu olduğu durumlarda olmak üzere, diş köklerini sinüslerle daha ilişkili seviyede göstermektedir. Bu yüzden hekim bazen gereksiz bir perforasyon beklentisine girse de, bu durum hasta açısından bir risk oluşturmaz. Panoramik radyografi diş kökü-sinüs ilişkisinin değerlendirilmesinde kullanılabilir ancak kesin tanı için KIBT tercih edilmelidir.

Anahtar kelimeler: Maksiller sinüs, pnömatizasyon, konik ışınlı bilgisayarlı tomografi, panoramik radyografi

\section{INTRODUCTION}

Pneumatization is a physiological process that occurs in all paranasal sinuses throughout the growth period, resulting in expansion of sinus volumes ${ }^{1,2}$ At the age of 20 years, following the eruption of the third molars, the pneumatization of the maxillary sinus ends and the floor of the sinus reaches $5 \mathrm{~mm}$ inferior to the nasal floor. ${ }^{1,3-5}$ However, a highly variable rate of additional or extensive pneumatization of the maxillary sinus may be observed among individuals and the floor of the maxillary sinus may expand between the roots of the adjacent teeth or into the edentulous space between the teeth, causing alveolar depressions (alveolar pneumatization).,36

The relationship of the maxillary sinus floor with the roots of the maxillary posterior teeth changes depending on the degree of alveolar pneumatization. ${ }^{7}$ Understanding of the alveolar pneumatization and the relation between teeth roots and sinus is crucial and needs to be considered in order to prevent potential complications after surgical procedures (e.g. implantation, tooth extraction and treatment of lesions) involving maxillary posterior region. ${ }^{8-10}$

Panoramic imaging is a practical tool that provides general information on the bone and anatomic structures and panoramic radiographs are commonly used for evaluation of bone height and pneumatization for implant recipient sites at dental clinics where cone-beam com- puted tomography (CBCT) is unavailable. ${ }^{11}$ However, panoramic radiography can only give two-dimensional information for assessment of sinus pneumatization and the tooth root- sinus relationship, ${ }^{7-10}$ failing to provide a clear view of structures other than focal trough; also, image magnification dictated by the imaging algorithm and distortions ultimately limit measurements of alveolar bone height and root length. ${ }^{11}$ On the other hand, CBCT is a three-dimensional imaging technique that has been specifically designed to offer better visualization of anatomic structures of the head and neck regions. CBCT produces undistorted, true-scale images and is considered as the gold standard method for imaging maxillary sinuses. ${ }^{8-11}$

The prevalence of pneumatization is highly variable, with rates ranging from $8 \%$ to $32 \%$ reported by studies from different countries. ${ }^{12-14}$ A study from Turkey reported a prevalence of $27.7 \%{ }^{15}$

The primary purpose of the present study was to determine the sensitivity, specificity and diagnostic accuracy of panoramic imaging for assessment of pneumatization and the relation of tooth root with sinus as compared to CBCT. Secondarily, we aimed to establish the prevalence of pneumatization and its potential relationships with sinus pathologies in a Turkish subpopulation using the CBCT.

\section{MATERIALS AND METHODS}

This study was designed as a retrospective chart review of patients presenting to Cumhuriyet University Faculty of Dentistry between 2015 and 2016 for various reasons including implantation, cystic or tumoral jaw lesions whose both panoramic and CBCT images were available. This study is in conformity with the declaration of Helsinki. Approval for the conduct of the study was obtained from Cumhuriyet University Ethics Committee for Non-Interventional Clinical Studies on 23.12.2016 (no. 201612/16) before initiation of the study. 'Informed Consent Form' was obtained from the patients who were included in the study.

One thousand CBCT images (Planmeca ProMax 3D Mid, Planmeca Oy, Finland) were reviewed retrospectively prior to the study. Among patients aged 20 years and older with both panoramic radiographs (Instrumentarium OP200, Instrumentarium Dental, Finland) and CBCT images involving bilateral maxillary sinuses available, a total of $300 \mathrm{CBCT}(8 \varnothing \times 8,10 \varnothing \times 6$ or $20 \varnothing \times 10 \mathrm{~cm}$ FOV; 90 kV, 10 $\mathrm{mA}, 150 \mu \mathrm{m}$ resolution) and panoramic images from 143 (47.7\%) males and 157 (52.3\%) females were included in the study.

To evaluate the repeatability of assessment of the study images, 2 experts (one specialist and one research fellow) from the Department of Oral and Maxillofacial Radiology scored randomly selected 75 CBCT and panoramic imag- 
es with respect to study parameters 2 weeks apart. The experts demonstrating a good repeatability level scored all images for the study parameters, namely, the presence of alveolar pneumatization, sinus pathologies and tooth root-sinus relationship and СBCT imaging was considered as the gold standard for the study.

The presence of one or more posterior maxillary teeth in the proximity of a canine was considered to indicate "the presence of tooth". The anatomical relationship between the floor of the maxillary sinus and roots of maxillary posterior teeth was examined and extension of the maxillary sinus floor around the roots of the teeth indicated "the presence of pneumatization" (Figure 1).

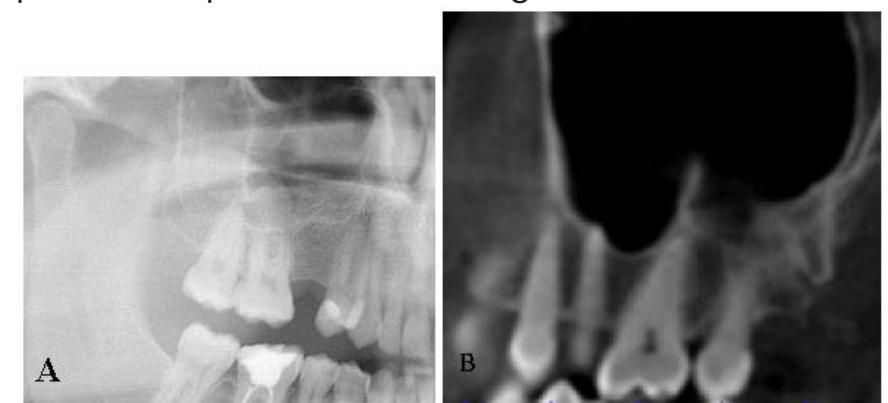

Figure 1. Presence of pneumatization in dentulous and edentulous areas as demonstrated by two different imaging methods; A. Panoramic radiography, B. BCT (cone-beam computed tomography)

Given the fact that maxillary sinus develops until the floor of the sinus lies $5 \mathrm{~mm}$ inferior to the nasal floor, ${ }^{1}$ any values exceeding these physiological limits were considered to indicate "the presence of pneumatization" in the posterior edentulous sites (Figure 2).
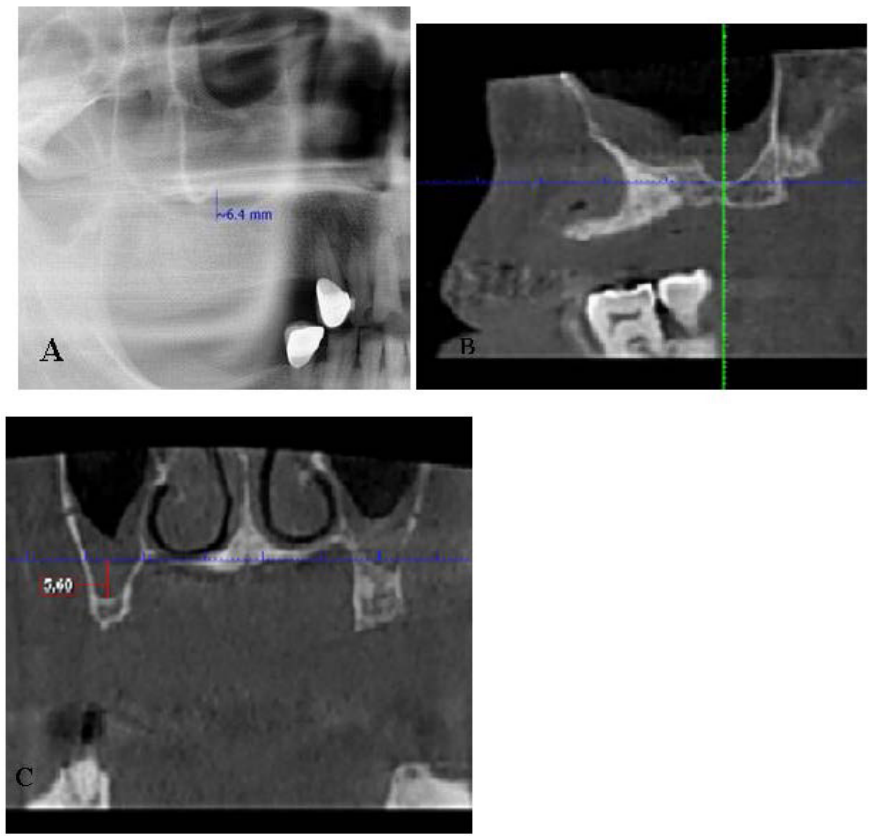

Figure 2. A. Pneumatization in the edentulous area determined by panoramic radiography; $\mathrm{B}$. Pneumatization in the edentulous area determined by CBCT imaging by detecting the deepest point of the sinus in sagittal plane and $\mathrm{C}$. by measurement of the distance from the nasal floor to the sinus floor in coronal plane.

Irrespective of the type and location of the tooth and the number of roots of each tooth located in the maxillary posterior area, any maxillary posterior tooth with any roots causing interruption of the maxillary sinus floor was considered as "projection of root apices in the sinus", any tooth with the root tip in contact with the sinus floor or borderline was considered as having "roots neighboring to the sinus" and any tooth with the root tip located below or more distantly from the cortical bone of the sinus was considered as having "roots distant from the sinus" (Figure 3).
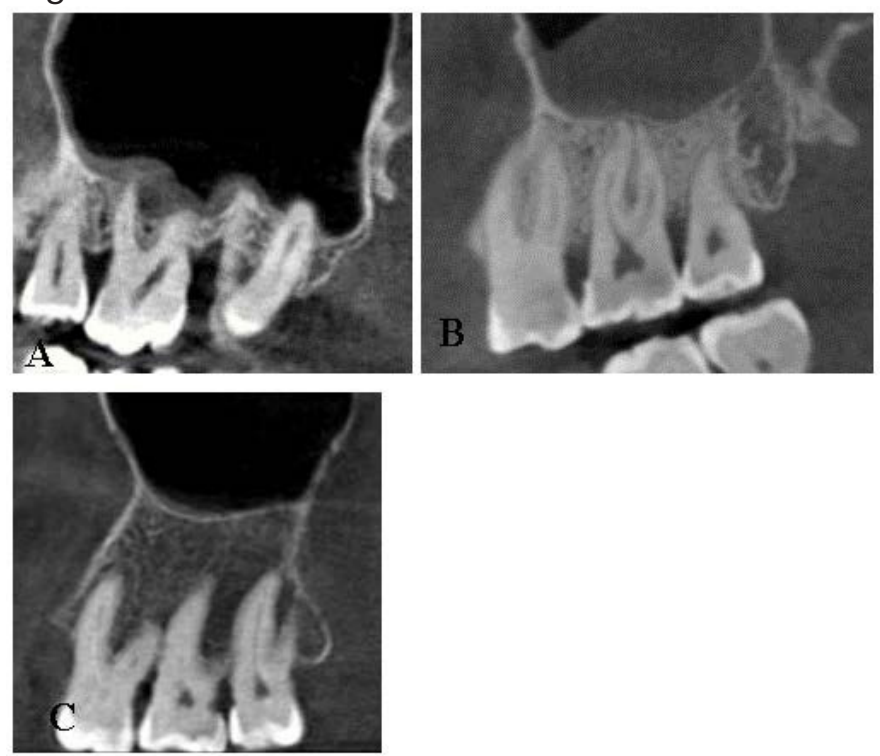

Figure 3. СВСТ images showing A. Tooth root projecting into the sinus, B. Tooth root neighboring the sinus, $\mathrm{C}$. Tooth root distant from the sinus.

Mucosal thickening of the maxillary sinus floor was classified as present or absent. Since mucosa of a normal thickness $(1 \mathrm{~mm})$ cannot be visualized by radiography, ${ }^{16}$ a slight increase in opacity observed in the maxillary sinus floor was considered as mucosal thickening. All sinus pathologies such as air-fluid level, mucous retention cyst apart from mucosal thickening were classified as "other pathologies". СВCT images were examined for findings of mucosal thickening and sinus pathologies.

\section{Statistical Analysis}

Statistical analyses of the study data were performed using the SPSS (ver. 22.0) software.

Intra-rater agreement of the two observers individually for assessment of СВCT images and panoramic radiographs and inter-rater agreement of the observers for the first and second readings were calculated using kappa statistics. A kappa ( $\mathrm{K}$ ) coefficient value less than 0 implies poor agreement, a value between 0 and 0.20 implies fair agreement, 0.21 to 0.40 implies moderate agreement, 0.41 to 0.60 implies acceptable agreement, 0.61 to 0.80 implies significant agreement and 0.81 to 1.00 indicates perfect agreement.

Chi-square test was used to evaluate factors related to alveolar pneumatization and sinus pathologies. For the purposes of statistical analysis, patients were stratified into 5 groups based on age: age 20 to 29 years ( $n=67), 30$ to 39 years ( $n=50), 40$ to 49 years $(n=69), 50$ to 59 years $(n=74)$ and 60 years of age or older $(n=40) .{ }^{17}$ Statistical significance was considered when a $p$ was less than 0.05 . The sensitivity, specificity, diagnostic accuracy, positive 
and negative predictive values and false positive and false negative rates were estimated for panoramic imaging as compared to the gold standard СВСТ findings.

\section{RESULTS}

Intra-rater agreement of each observer for assessment of study parameters of pneumatization and tooth root-sinus relationship on panoramic radiographs and CBCT images was perfect (0.925-0.985). For CBCT, inter-rater agreement was perfect for both readings of pneumatization (0.953-1.000) and significant for the first CBCT reading of tooth root-sinus relationship (0.694). For panoramic radiography, inter-rater agreement for both parameters was significant at the first reading (0.671-0.757) and perfect at the second reading (0.820-0.840).

CBCT images showed the presence of alveolar pneumatization in 244 (81.3\%) of 300 patients. Alveolar pneumatization was unilateral in $15 \%$ and bilateral in $66.3 \%$ of the patients. Sinus mucosal thickening was detected in $63 \%$ and other pathologies in $31.7 \%$ of the patients.

While there was no statistically significant age-related difference in study parameters ( $p>0.05$ ), significant differences were found between age groups in alveolar pneumatization and tooth root-sinus floor relationship $(p<0.05)$ (Table 1).

Table 1. Study parameters in relation to age groups.

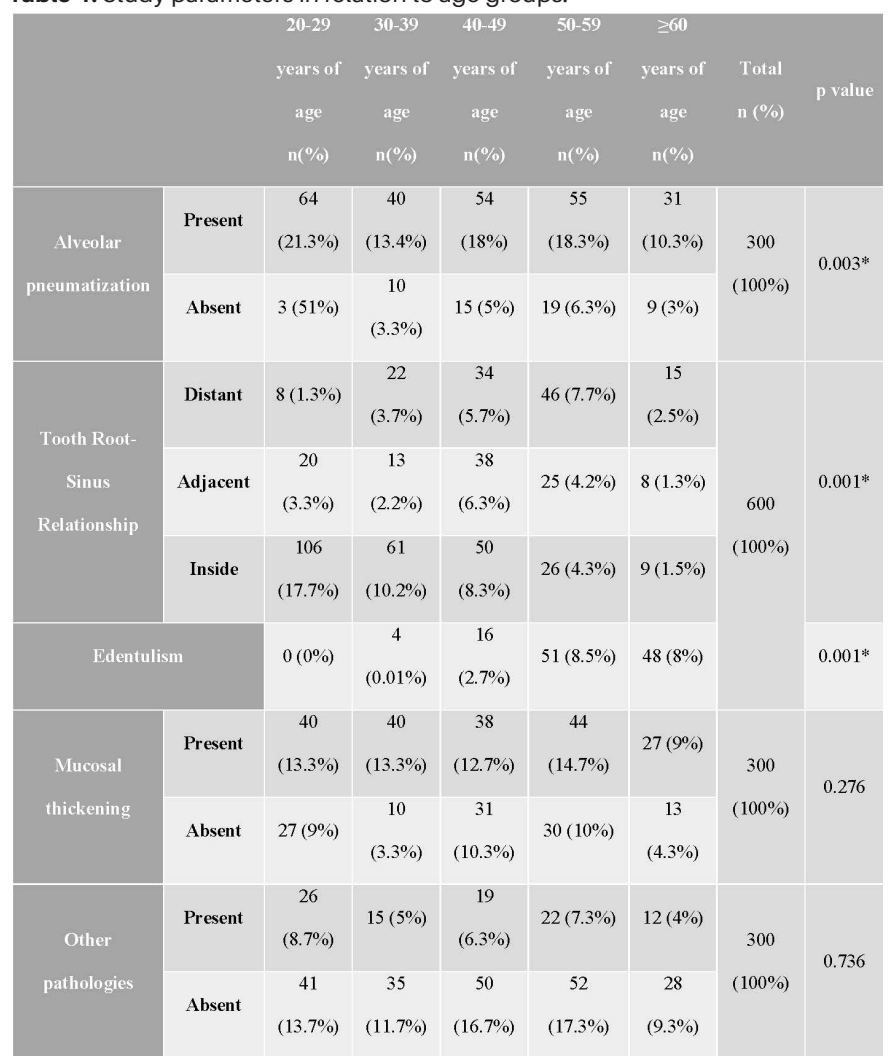

Chi-square test. * $p<0.05$

Presence of tooth was statistically significantly associated with alveolar pneumatization $(\mathrm{p}<0.05)$ (Table 2).
Table 2. Relations between the presence/absence of tooth and alveolar pneumatization

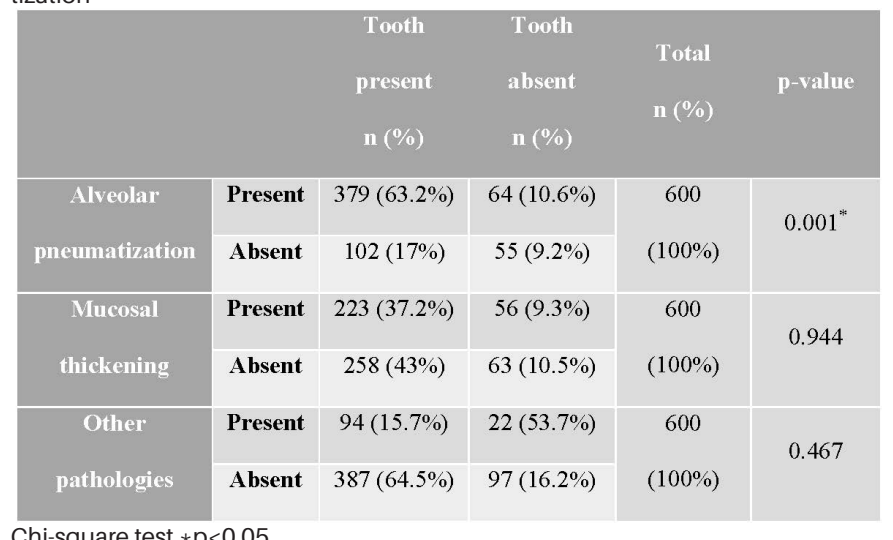

Panoramic radiography failed to accurately locate tooth roots in $64.4 \%$ of the cases as projecting into the sinus when in fact they were adjacent to the sinus as detected by CBCT and $21.1 \%$ of the tooth roots were falsely located at an upper level as being inside the sinus or borderline when they were in fact distant from the sinus (Table 3 ).

Table 3. Actual positioning of the relationship of tooth root with sinus (CBCT) as compared to the positioning on panoramic radiographs

\begin{tabular}{|c|c|c|c|c|}
\hline \multirow{2}{*}{\begin{tabular}{c}
\multirow{2}{*}{ Tooth Root-Sinus } \\
Relationship
\end{tabular}} & \multicolumn{2}{c|}{ Positioning on Panoramic Radiographs } \\
\cline { 3 - 5 } \multirow{2}{*}{ Actual Positioning (CBCT) } & Anside & Adjacent & Distant \\
\hline Inside & $252(100 \%)$ & $239(94.8 \%)$ & $11(4.4 \%)$ & $2(0.8 \%)$ \\
\hline Adjacent & $104(100 \%)$ & $67(64.4 \%)$ & $26(25 \%)$ & $11(10.6 \%)$ \\
\hline Distant & $128(100 \%)$ & $10(7.8 \%)$ & $17(13.3 \%)$ & $101(78.9 \%)$ \\
\hline
\end{tabular}

Overall, panoramic radiographs showed a high sensitivity for locating tooth roots protruding into the maxillary sinus (96.8\%) but lower sensitivity for locating tooth roots neighboring the sinus $(26.3 \%)$. Panoramic radiographs had a comparable and high specificity for locating tooth roots distant from or adjacent to the maxillary sinus (96.3\% and $96.7 \%$, respectively). Panoramic radiographs showed a high sensitivity for detecting alveolar pneumatization (97.7\%) whereas its specificity was lower (62.1\%) (Table 4).

Table 4. Efficiency of panoramic radiography versus СВСТ

\begin{tabular}{|c|c|c|c|c|}
\hline & \multicolumn{3}{|c|}{ Alveolar } & \multicolumn{2}{|c|}{ Tooth Root-Sinus Relationship } \\
\hline & Pneumatization & Distant & Adjacent & Inside \\
\hline Sensitivity & $97.7 \%$ & $85.2 \%$ & $26.3 \%$ & $96.8 \%$ \\
\hline Specificity & $62.1 \%$ & $96.3 \%$ & $96.7 \%$ & $78.7 \%$ \\
\hline False Positive & $37.8 \%$ & $3.6 \%$ & $3.2 \%$ & $21.2 \%$ \\
\hline False Negative & $2.2 \%$ & $14.8 \%$ & $73.7 \%$ & $3.1 \%$ \\
\hline Positive Predictive Value & $88.7 \%$ & $82.6 \%$ & $65.2 \%$ & $76.7 \%$ \\
\hline Negative Predictive Value & $90.1 \%$ & $96.3 \%$ & $84.8 \%$ & $97.1 \%$ \\
\hline Diagnostic Accuracy & $89 \%$ & $94 \%$ & $83.3 \%$ & $86.3 \%$ \\
\hline
\end{tabular}

\section{DISCUSSION}

One of the common changes in the volume and configuration of the maxillary sinus involves posterior extension toward the zygoma and inferior pneumatization into the dental alveolus about the roots of the posterior teeth or 
between them in edentulous areas. ${ }^{18}$

A wide range of prevalence rates have been reported in the literature for alveolar pneumatization in the maxillary sinus, ranging from $8 \%$ to $83.2 \% .^{12-15,19}$ In a 2010 study, Lana et al. ${ }^{13}$ identified alveolar pneumatization in $83.2 \%$ of the Brazilian population. Kalavagunta and Reddy ${ }^{12}$ reported maxillary sinus pneumatization in $8 \%$ of the UK population in 2003 , whereas Gocmen et al. ${ }^{15}$ reported an alveolar pneumatization of $27.7 \%$ in a Turkish subpopulation residing in the Marmara region in 2015. In the present study, alveolar pneumatization was found at a higher rate compared to that previously reported from a Turkish subpopulation and at a similar prevalence with Lana et al.'s ${ }^{13}$ study. Therefore, a highly variable prevalence of pneumatization was also shown for Turkish population at a regional level. We believe that this discrepancy may have resulted from differences in methodology or studied subpopulations and further studies are needed for standardization of pneumatization criteria.

Studies on the frequency of pneumatization reported a higher rate of bilateral pneumatization, ${ }^{12-14,19}$ which is consistent with our findings.

Gocmen et al. ${ }^{15}$ found comparable rates of alveolar pneumatization in both sexes but Kalavagunta and Reddy ${ }^{12}$ reported a higher prevalence among females. Our findings are consistent with those of Gocmen et al. ${ }^{15}$

In contrast with the general understanding that pneumatization increases with advancing age, ${ }^{11}$ pneumatization was most common in the 20-29 age group and the least common among patients 60 years of age or older in our study. These findings may be attributed to the use of 2 separate criteria (observational and measurement-based) for dentulous and edentulous areas for the definition of pneumatization or small sample size in these age groups as well as potential calibration issues with the СВCT device (even a small deviation of $1 \mathrm{~mm}$ ).

Similar to our study findings, Kılıc et al.20 did not find any statistically significant differences between sexes in the tooth root-sinus relationship as detected by CBCT.

Normally, the maxillary sinus mucosa is about $1 \mathrm{~mm}$ thick and not visualized on a radiograph. However, the mucosa thickness may increase when it becomes inflamed and may be seen radiographically; any mucosal thickening is considered pathological. ${ }^{16}$ We evaluated mucosal thickening based on this criterion in the present study and found a prevalence of $63 \%$ which closely matched the mucosal thickening prevalence of $48.8 \%$ as reported by Lu et al. ${ }^{21}$ but Perez et al. ${ }^{14}$ reported a lower mucosal thickening prevalence of $27.5 \%$.

While the thickness of sinus membrane may greatly vary among healthy individuals, males are more likely to be affected by mucosal thickening as compared to females. ${ }^{22}$ Phothikhun ${ }^{23}$ and Sheikhi ${ }^{24}$ reported greater mucosal thickening frequencies among males versus females and Sheikhi ${ }^{24}$ found a significant association between gender and mucosal thickening $(p<0.05)$. In the current study, mucosal thickening was detected at a higher rate in male patients in comparison to female patients but the difference between sexes did not reach statistical significance $(p>0.05)$.

Lopes et al. ${ }^{25}$ compared panoramic radiographs and СВCT images for assessing topographic relationship of maxillary teeth with sinus floor and found a significant difference between the two methods. Panoramic radiog raphy was reported to overestimate the projection of the roots into the sinus and underestimate the distance between the roots and the sinus.

Consistent with Lopes et al.'s ${ }^{25}$ study, tooth roots were falsely located in an upper position by panoramic radiographs when $\mathrm{CBCT}$ showed that they were actually adjacent to the sinus floor, leading to a rating of "projection of the root into the sinus" in the current study. Additionally, panoramic radiographs underestimated the distance to the bone and falsely identified $21.1 \%$ of the tooth roots as being adjacent to or projecting into the sinus, when in fact they were distant from the sinus.

\section{CONCLUSION}

In light of these data, when planning treatment for the teeth that appear to be adjacent to the sinus on radiography, consideration should be given to the fact that panoramic radiographs may underestimate the distance from the root to the maxillary sinus and the distance may actually be greater than that seen on radiography.

Panoramic radiography had a lower, albeit acceptable specificity (78.2\%) for determining projection of the root into the sinus cavity when compared with its sensitivity. Negative projection angles ((- 4) - (- 7)) used for panoramic imaging may have led to a distorted view of all of these root protrusions into the sinus. ${ }^{26,27}$ However, such distortions encountered in panoramic imaging do not pose a risk for patients but should urge the dentist to undertake preoperative work-up more carefully.

\section{REFERENCES}

1. Sharan A, Madjar D. Maxillary sinus pneumatization following extractions: a radiographic study. Int J Oral Maxillofac Implants 2008; 23: 48-55.

2. Lee J-E, Jin S-H, Ko Y, Park J-B. Name of journal: World Journal of Clinical Cases ESPS Manuscript No: 10592 Columns: Minireview Evaluation of anatomical considerations in the posterior maxillae for sinus augmentation.

3. Wagner F, Dvorak G, Nemec S, Pietschmann P, Figl M, Seemann R. A principal components analysis: how pneumatization and edentulism contribute to maxillary atrophy. Oral Diseases 2017; 23: 55-61.

4. Scuderi AJ, Harnsberger HR, Boyer RS. Pneumatization of the paranasal sinuses: normal features of importance 
to the accurate interpretation of CT scans and MR images. AJR Am J Roentgenol 1993; 160: 1101-1104.

5. Baykara M. ve ark., Maxillary Sinus Aplasia. Tübitak, 2002.

6. Hauman C, Chandler N, Tong D. Endodontic implications of the maxillary sinus: a review. Int Endod 2002; 35: 127-141.

7. Stuart C. White MJP. Oral Radiology Principles and Interpretation. 7th ed. 2014.

8. Hassan BA. Reliability of periapical radiographs and orthopantomograms in detection of tooth root protrusion in the maxillary sinus: correlation results with cone beam computed tomography. J Oral \& Maxillofac Res 2010; 1: e6.

9. Eggesbø H. Radiological imaging of inflammatory lesions in the nasal cavity and paranasal sinuses. European Radiol 2006; 16: 872-888.

10. Kronemer KA, McAlister W. Sinusitis and its imaging in the pediatric population. Pediatric Radiol 1997; 27: 837-846.

11. Diş Hekimliğinde Radyolojinin Esasları. 1 ed. İstanbul 2017.

12. Kalavagunta $S$, Reddy K. Extensive maxillary sinus pneumatization. Rhinology 2003; 41: 113-117.

13. Pelinsari LJ, Moura RCP, de Carvalho MV, de Souza EAP, Ricordo MF, Campolina RHM. Anatomic variations and lesions of the maxillary sinus detected in cone beam computed tomography for dental implants. Clin Oral Imp Res 2012; 23: 1398-1403.

14. Sánchez-Pérez A, Boracchia AC, López-Jornet $P$, BoixGarcía P. Characterization of the Maxillary Sinus Using Cone Beam Computed Tomography. A Retrospective Radiographic Study. Implant Dent 2016; 25: 762-769.

15. Göçmen G, Borahan MO, Aktop S, Dumlu A, Pekiner FN, Göker K. Effect of Septal Deviation, Concha Bullosa and Haller's Cell on Maxillary Sinus's Inferior Pneumatization; a Retrospective Study. Open Dent J 2015; 9: 282.

16. Borahan MO, Keser G. Paranazal Sinüslerin Benign Lezyonları. Turkiye Klinikleri Journal Oral and Maxillofac Radiol-Special Topics. 2017; 3: 149-157.

17. Raghav M, Karjodkar FR, Sontakke S, Sansare K. Prevalence of incidental maxillary sinus pathologies in dental patients on cone-beam computed tomographic images. Contemp Clin Dent 2014; 5: 361-365.

18. Lawson W, Patel ZM, Lin FY. The development and pathologic processes that influence maxillary sinus pneumatization. Anatomical Record 2008; 291: 1554-1563.

19. Shahidi S, Zamiri B, Danaei SM, Salehi S, Hamedani S. Evaluation of anatomic variations in maxillary sinus with the aid of cone beam computed tomography (CBCT) in a population in south of Iran. J Dent 2016; 17: 7.

20. Kilic C, Kamburoglu K, Yuksel SP, Ozen T. An assessment of the relationship between the maxillary sinus floor and the maxillary posterior teeth root tips using dental cone-beam computerized tomography. Eur J Dent 2010; 4: 462-467.

21. Lu Y, Liu Z, Zhang L, et al. Associations between maxillary sinus mucosal thickening and apical periodontitis using cone-beam computed tomography scanning: a retrospective study. J Endod 2012; 38: 1069-1074.

22. Dental CT Third Eye in Dental Implants. 1 ed. India 2013.

23. Phothikhun $S$, Suphanantachat $S$, Chuenchompoonut V, Nisapakultorn K. Cone-beam computed tomographic evidence of the association between periodontal bone loss and mucosal thickening of the maxillary sinus. J Periodontol 2012; 83: 557-564.

24. Sheikhi M, Pozve NJ, Khorrami L. Using cone beam computed tomography to detect the relationship between the periodontal bone loss and mucosal thickening of the maxillary sinus. Dent Res J 2014; 11: 495-501.

25. Lopes LJ, Gamba TO, Bertinato JV, Freitas DQ. Comparison of panoramic radiography and CBCT to identify maxillary posterior roots invading the maxillary sinus. Dentomaxillofac Radiol 2016; 45: 20160043.

26. Abubekir Harorlı HMA, Saadettin Dağistan. Dişhekimliği Radyolojisi. Erzurum 2006.

27. Langland O, Langlais R. Principles of dental imaging. [USA]: Lippincott W. Wilkins; 1997. 